chosen scientists, behind closed doors.

In September 2016, Renzi floated the idea of creating 500 elite professorships known as Natta chairs (after Italian chemist and Nobel laureate Giulio Natta), to be awarded mainly to Italians working abroad. They would be selected by 25 evaluation panels whose chairs the prime minister would nominate. Thousands of academics signed an open letter in October complaining that Renzi had designed the programme without discussing it with universities. The letter also protested against the involvement of politics in the selection.

Regulations for the Natta selection procedure have not yet been published, and so scientists hope that the next govern-

"This means
that weaker
universities in
the south will
lose even more
money."
ment will ensure that the process remains inside the academic community.

"Nomination of panel chairs by the prime minister is just not acceptable," says physicist Giorgio Parisi of the University of Rome La Sapienza, a prominent critic of the process. "It is a political choice to do the selection independently of Italian universities, but then you could turn to external academic organizations, like Europe's national academies."

\section{BUDGETARY BLUES}

Parisi is also unhappy with aspects of the 2017 universities budget. In particular, $€ 271$ million will now be reallocated to the university departments that are judged by the national evaluation agency ANVUR to have the best research performance. Parisi thinks that rewards for high performers should come from new money, rather than being transferred from a general university budget that is already stretched thin. "This government reallocation means that weaker universities in the south will lose even more money, and this would be a social disaster," he says.

An interim government will hold down the fort until new elections are held, which could take place next year. Uncertainty is set to continue. Populist and protest parties, particularly the Five Star Movement led by comedian Beppe Grillo, are likely to make substantial gains in the next election.

These parties do not have strong scientific agendas. Italian senator-for-life Elena Cattaneo, who is also a neuroscientist at the University of Milan, is taking a waitand-see perspective. "One or two populists in the current parliament have shown themselves to be more open to discussion on scientific topics than members of mainstream parties," she says.

\section{Impact factor gets heavyweight rival}

\section{CiteScore uses larger database and gets different results.}

\section{BY RICHARD VAN NOORDEN}

$\mathrm{O}$ ne of science's most contentious metrics has a flashy new rival. On 8 December, publishing giant Elsevier launched the CiteScore index to assess the quality of academic journals.

Although the index ranks journals with a formula that largely mimics the influential Journal Impact Factor (JIF), it covers twice as many journals - 22,000 to the JIF's 11,000 and its formula includes tweaks that produce some notably different results. These include lower scores for some high-JIF journals (see 'A new measure of journal impact?').

If CiteScore becomes popular, these quirks could change the behaviour of journals hoping to maximize their score, say analysts. But CiteScore's debut comes at a challenging time is an appetite for a competitor to the JIF, and scientists note that no matter what differences CiteScore provides, it will have to survive the same criticisms that are lobbed at its rival most notably that the JIF is so commonly promoted by publishers as a yardstick for 'quality' that researchers are judged by the impact factor of the journal in which their work appears, rather than by what they actually write.

"In my view, journal metrics should always be accompanied by health warnings that are at least as prominent as the ones you see for such metrics. It's not obvious that there on cigarette packets," says Stephen Curry, a structural biologist at Imperial College London. "Such metrics are at the root of many of the current evils in research assessment."

Amsterdam-based Elsevier has for many years provided a suite of analytical indicators, including journal metrics that have never become as popular as the JIF. It says that it has launched CiteScore owing to "overwhelming demand" from authors and editors.

The publisher is uniquely placed to challenge the JIF's hegemony. It owns the Scopus database, a record of article abstracts and their reference lists. Aside from Web of Science, on which the JIF is based, it is the world's only reasonably comprehensive and carefully curated citation database. But Scopus is bigger, enabling scientists, librarians and funders to check the popularity of many more journals. Furthermore, unlike the JIF, which is available only to subscribers, CiteScore figures will be free online for anyone to view and analyse, although full details of the documents included in the calculations are visible only to subscribers.

When it comes to their underlying formulae, CiteScore and JIF are near-doppelgängers. To score any journal in any given year, both tot up the citations received to documents that were published in previous years, and divide that by the total number of documents. The most popular version of the JIF looks at research articles published in the previous

\section{A NEW MEASURE OF JOURNAL IMPACT?}

Journals that have a high impact factor, a measure of the average number of citations that their articles receive, don't necessarily score so well on a new indicator, CiteScore. The latest metric includes documents such as editorials, letters and news items, which attract fewer scholarly citations.

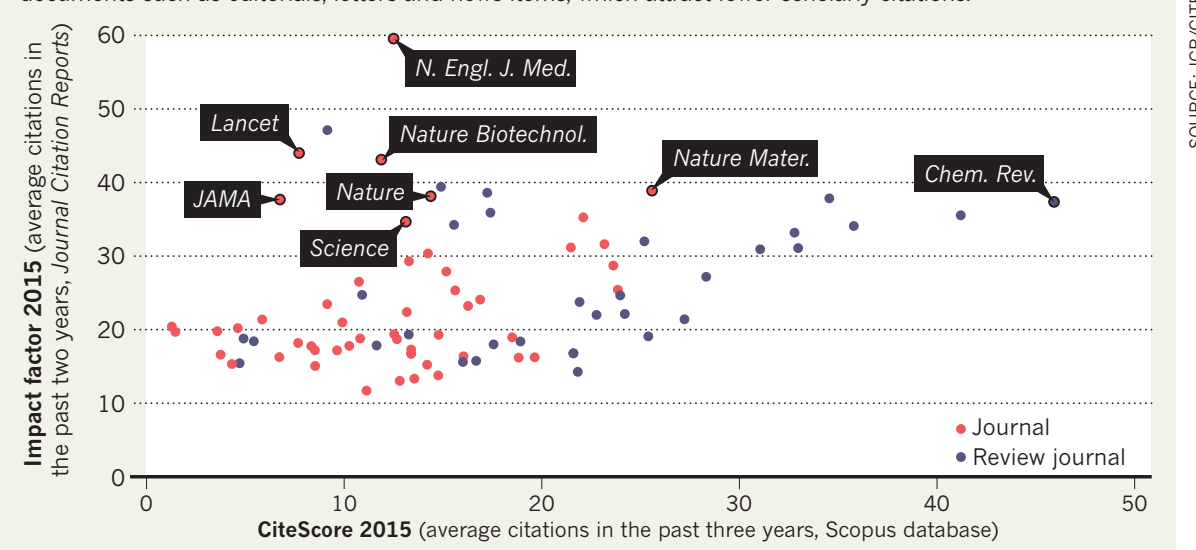

The highest-scoring journal on both measures is CA: A Cancer Journal for Clinicians with an impact factor of 138 and CiteScore 66. 
two years, whereas CiteScore counts the previous three.

But one significant difference leads some high-JIF journals, such as Nature, Science and The Lancet, to do worse in CiteScore. The new metric counts all documents as potentially citable, including editorials, letters to the editor, corrections and news items. These are less cited by scholars, so they drag down the average. The Lancet, for instance, drops from a healthy average of 44 in JIF - putting it in 4 th position - to 7.7 in CiteScore, outside the top 200.

Such a distinction could have major consequences for the behaviour of publishers. "As there is intense competition among top-tier journals, adoption of CiteScore will push editors to stop publishing non-research documents, or shunting them into a marginal publication or their society website," predicts Phil Davis, a publishing consultant in Ithaca, New York.

\section{NUANCED CONTENT}

The Lancet, Nature and other journals declined to comment on CiteScore. But Jeremy Berg, the editor-in-chief of Science, says that the journal is "very proud of our content that lies outside traditional research reports and articles" and that "any metric that is based on citation data alone will undervalue the impact of such nonresearch content".

"The portfolio performance of all publishers may look a bit different using CiteScore metrics, including Elsevier, but all publishers gain in that they can explore the performance of more of their titles because of the broader coverage of Scopus," says Lisa Colledge, director of research metrics at Elsevier. She says that CiteScore should be used only to compare related journals, not to compare raw scores across different fields. For example, the index ranks The Lancet 25 th out of 1,549 'general medicine' journals - putting it in the top 98th percentile of journals in that subject category.

Clarivate Analytics in Philadelphia, Pennsylvania, which bought the JIF and the Web of Science this year from Thomson Reuters, says that it doesn't see any new insights in CiteScore. Other, more complex metrics - including several published by Elsevier and Thomson Reuters - have been developed to rank journals in the past, but none has yet proved as popular as the JIF. "If anything, another, different metric will reinforce the status that the JIF has as the definitive assessment of journal impact," says Clarivate spokesperson Heidi Siegel.

Some even wonder whether Elsevier, which publishes more than 2,500 journals, should be producing CiteScore at all. The JIF has always been owned by non-publishers. "I question the appropriateness of a publisher getting involved with the metrics that evaluate the very content that it publishes," says Joseph Esposito, a publishing consultant in New York City. But Elsevier says that it is "a provider of information solutions as well as a publisher", and treats all the publishers it analyses equally.

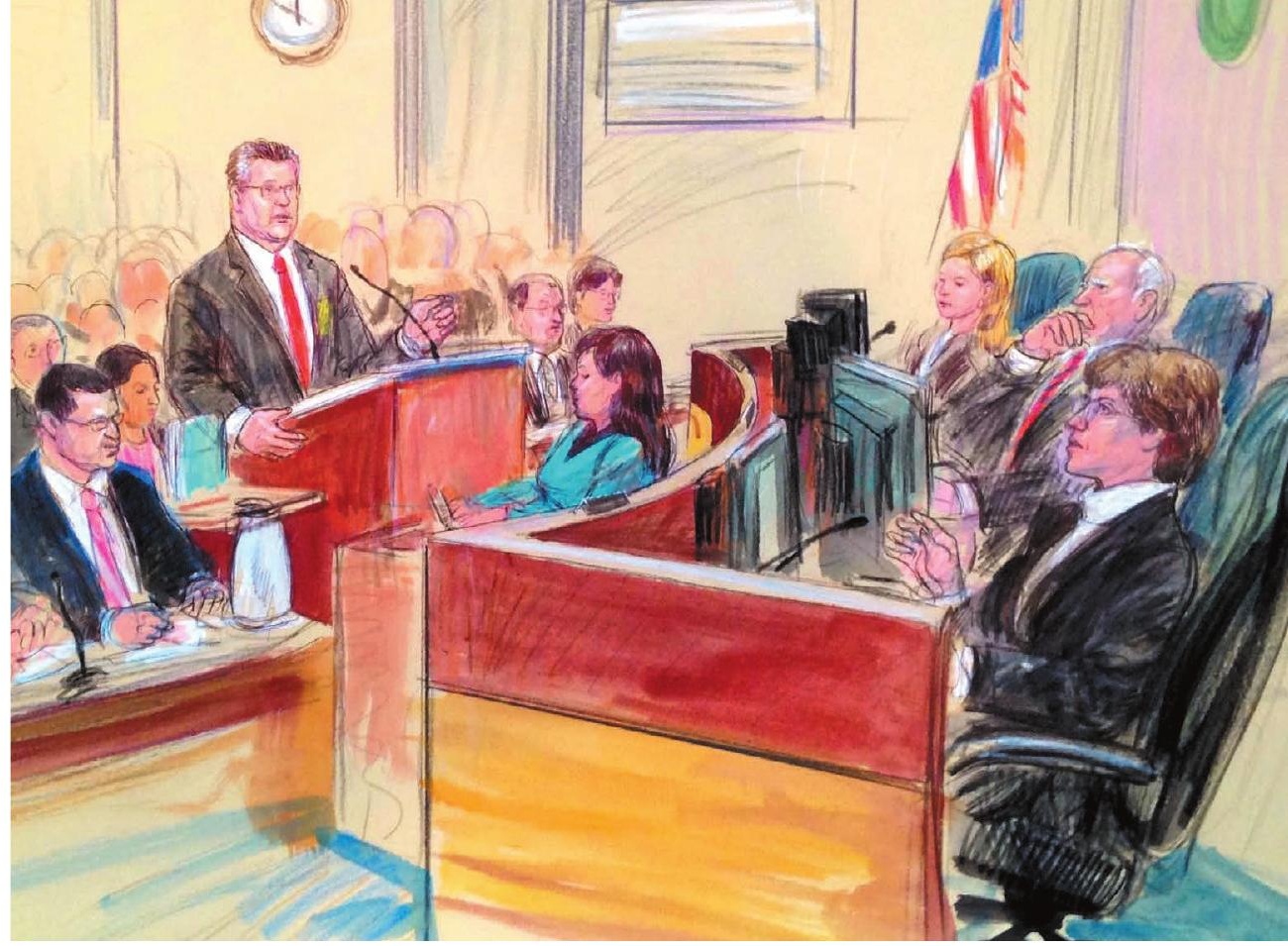

Lawyers for the University of California, Berkeley, and the Broad Institute faced off in patent court.

INTELLECTUAL PROPERTY

\section{CRISPR patent battle goes to court}

\section{Hearing focuses on use of gene editing in complex cells.}

\section{BY SARA REARDON, ALEXANDRIA, VIRGINIA}

I t was a tough day in US patent court for the University of California, Berkeley.

On 6 December, lawyers for the university laid out its claim to the geneediting tool CRISPR-Cas9 during a hearing at the US Patent and Trademark Office (USPTO) - and drew intense, sometimes sceptical, questioning from the three judges who will decide the fate of patents that could be worth billions of dollars.

Berkeley and its rival, the Broad Institute of MIT and Harvard in Cambridge, Massachusetts, are each vying for the intellectual property underlying CRISPR-Cas9, which is adapted from a system that bacteria use to fend off viruses. During the hearing in Alexandria, Virginia,

"My impression
is both will
end up with
something."
the USPTO judges challenged Berkeley's central claim: that once its researchers demonstrated that CRISPR-Cas9 could be used to edit DNA in bacteria, any reasonably skilled person could have adapted the technique for use in more complex cells.

If the court decides that is true, it would invalidate the patent now held by the Broad
Institute. But the Berkeley argument is a difficult one to make, given that it hinges on "a really subjective standard" - especially when applied to extraordinarily accomplished scientists such as those at the Broad, says Jacob Sherkow, a legal scholar at New York Law School in New York City.

\section{BYZANTINE BATTLE}

The patent fight began in May 2012, when Jennifer Doudna, a molecular biologist at Berkeley, filed for a patent after her research team used CRISPR-Cas9 to alter specific stretches of bacterial DNA. In December 2012, synthetic biologist Feng Zhang of the Broad Institute filed his own patent claim, demonstrating use of the gene-editing technique in more-complex eukaryotic cells, such as those from mice and humans. Zhang asked for - and was granted - an expedited review for his patent application.

The USPTO awarded him the rights to CRISPR-Cas9 in 2014. Berkeley then asked the patent office to investigate who first invented the gene-editing technique - a process known as a 'patent interference'. That review began in January. Over the past 11 months, the rival research institutions have filed hundreds of pages of documents with the court. 